\title{
PUBLIC-PRIVATE PARTNERSHIP SYSTEMS IN THE REPUBLIC OF KOREA, THE PHILIPPINES, AND INDONESIA
}

Kang-Soo Kim, Min-Woong Jung, Mee-Soo Park, Yoo-Eun Koh, and Jin-Oh Kim

\section{NO. 561 \\ ADB ECONOMICS \\ October 2018 WORKING PAPER SERIES}




\section{Public-Private Partnership Systems in the Republic of Korea, the Philippines, and Indonesia}

Kang-Soo Kim, Min-Woong Jung, Mee-Soo

Park, Yoo-Eun Koh, and Jin-Oh Kim

No. 561 | October 2018
Kang-Soo Kim (kskim@kdi.re.kr) is Senior Fellow and Jin-Oh Kim (kimjinoh@kdi.re.kr) is Senior Research Associate in the Department of Public Finance and Social Policy at the Korea Development Institute. Min-Woong Jung (mujung@kdi.re.kr) is Specialist, and Mee-Soo Park (mspark@kdi.re.kr) and Yoo-Eun Koh (kohy@kdi.re.kr)are Senior Research Associates in the Public and Private Infrastructure Investment Management Center at the Korea Development Institute.

This paper has been prepared as background material for the Asian Development Outlook (ADO) 2017 Update theme chapter on Sustaining Development through Public-Private Partnership. 
(C) 2018 Asian Development Bank

6 ADB Avenue, Mandaluyong City, 1550 Metro Manila, Philippines

Tel +632632 4444; Fax +6326362444

www.adb.org

Some rights reserved. Published in 2018.

ISSN 2313-6537 (print), 2313-6545 (electronic)

Publication Stock No. WPS189594-2

DOI: http://dx.doi.org/10.22617/WPS189594-2

The views expressed in this publication are those of the authors and do not necessarily reflect the views and policies of the Asian Development Bank (ADB) or its Board of Governors or the governments they represent.

ADB does not guarantee the accuracy of the data included in this publication and accepts no responsibility for any consequence of their use. The mention of specific companies or products of manufacturers does not imply that they are endorsed or recommended by ADB in preference to others of a similar nature that are not mentioned.

By making any designation of or reference to a particular territory or geographic area, or by using the term "country" in this document, $A D B$ does not intend to make any judgments as to the legal or other status of any territory or area.

This work is available under the Creative Commons Attribution 3.0 IGO license (CC BY 3.0 IGO)

https://creativecommons.org/licenses/by/3.o/igo/. By using the content of this publication, you agree to be bound by the terms of this license. For attribution, translations, adaptations, and permissions, please read the provisions and terms of use at https://www.adb.org/terms-use\#openaccess.

This CC license does not apply to non-ADB copyright materials in this publication. If the material is attributed to another source, please contact the copyright owner or publisher of that source for permission to reproduce it. $\mathrm{ADB}$ cannot be held liable for any claims that arise as a result of your use of the material.

Please contact pubsmarketing@adb.org if you have questions or comments with respect to content, or if you wish to obtain copyright permission for your intended use that does not fall within these terms, or for permission to use the ADB logo.

Notes:

In this publication, “\$” refers to United States dollars.

ADB recognizes "Korea" as the Republic of Korea.

Corrigenda to ADB publications may be found at http://www.adb.org/publications/corrigenda. 


\section{CONTENTS}

TABLES AND FIGURES

ABSTRACT $v$ V

$\begin{array}{ll}\text { I. INTRODUCTION } & 1\end{array}$

II. LEGAL AND REGULATORY FRAMEWORK 2

A. Republic of Korea $\quad 2$

B. Philippines 3

C. Indonesia 3

III. PUBLIC-PRIVATE PARTNERSHIPIMPLEMENTATION PROCESSES 4

A. Republic of Korea $\quad 4$

B. Philippines $\quad 5$

C. Indonesia $\quad 7$

IV. PUBLIC-PRIVATE PARTNERSHIPINSTITUTIONAL FRAMEWORKS 9

A. Republic of Korea 9

B. Philippines 10

C. Indonesia 10

V. GOVERNMENT SUPPORT FOR PUBLIC-PRIVATE PARTNERSHIPS 11

A. Republic of Korea $\quad 11$

B. Philippines 15

$\begin{array}{ll}\text { C. Indonesia } & 17\end{array}$

VI. COMPARATIVE ANALYSIS

A. Legal and Regulatory Framework 18

B. Procurement Process 19

C. Well-Functioning Institutions 19

D. Risk Sharing 20

VII. POLICY RECOMMENDATIONS AND CONCLUSION 20

$\begin{array}{ll}\text { REFERENCES } & 23\end{array}$ 


\section{TABLES AND FIGURES}

\section{TABLES}

1 Approval Procedures for Public-Private Partnership in the Philippines

2 Government Organizations Promoting Public-Private Partnership Systems in the Republic of Korea

3 Government Organizations Promoting Public-Private Partnership Systems in the Philippines

$4 \quad$ Government Organizations Promoting Public-Private Partnership Systems in Indonesia

5 Exemption from Charges and Taxes for Public-Private Partnership Projects in the Republic of Korea

\section{FIGURES}

1 Public-Private Partnership Procurement Process Options for Solicited Proposals 7

2 Public-Private Partnership Procurement Process for Solicited Proposals 8

3 Mechanism of a Build-Transfer-Operate Risk-Sharing Scheme in the Republic of Korea 12

4 Mechanism of a Build-Transfer-Operate-Adjusted Scheme in the Republic of Korea 13

5 Project Development and Monitoring Fund Flow Chart of the Philippines 16 


\begin{abstract}
Infrastructure plays a critical role in boosting the economy's overall productivity and development toward improving the quality of life. Public-private partnership (PPP) is considered as one of the key modalities for sustainable infrastructure development. This paper analyzes and compares the PPP systems in the Republic of Korea, the Philippines, and Indonesia to identify the requirements for making this modality an effective catalyst for infrastructure's contribution to sustainable development. These countries have used the increased capacity and transactional experience in handling these partnerships to develop their PPP markets and strengthen their institutional framework to increase the use of PPPs to provide infrastructure services. A comparative analysis is then conducted to draw lessons for other economies in developing Asia seeking to improve the efficiency and effectiveness of their PPPs. The analysis underscores how strong institutions, unified procurement frameworks, and effective dispute resolution mechanisms can improve the implementation of infrastructure PPPs.
\end{abstract}

Keywords: infrastructures, legal and institutional frameworks, public-private partnership

JEL codes: $\mathrm{H} 40, \mathrm{H} 50, \mathrm{O} 20$ 


\section{INTRODUCTION}

Properly selected and well-developed infrastructure can boost industrial competitiveness by enhancing productivity and the capacity to innovate, as well as reducing poverty and, thus, improving social welfare (IDB 2014). More often than not, fiscal resources have been insufficient to provide the needed infrastructure investment. Developing Asia needs to invest a total of $\$ 26$ trillion from 2016 to 2030 to meet the infrastructure needs including climate-related costs of the region (ADB 2017a). In 2015 , the region invested 5.5\% of gross domestic product or $\$ 881$ billion which is less than the required investment of $\$ 1.7$ trillion annually. ${ }^{1}$ The public sector can provide around $40 \%$ of the gap through public finance reforms and the rest can be financed by tapping private sector resources.

A new model for getting the investment needed to modernize and supply infrastructure is required, and governments have turned to the private sector as a partner in the provision of infrastructure services to reduce serious investment gaps by broadening financing options for infrastructure investment.

The public-private partnership (PPP) modality is considered a key instrument to attract muchneeded private investment for infrastructure development (ADB 2017b). It can help improve and streamline public services by taking advantage of the private sector's know-how and innovativeness and provide better oversight and regulation through a clear separation between service provider and regulator. From the perspective of the private sector, PPP projects also create stable, long-term investment opportunities by stimulating the development of financial markets that result in safe and reliable places to invest long-term capital.

PPP modality is gaining momentum in the Asia and Pacific region and governments across the region have improved in terms of PPP readiness (EIU 2015). This paper analyzes and compares the PPP systems in the Republic of Korea, the Philippines, and Indonesia and shows how this modality can be an effective catalyst for infrastructure's contribution to sustainable development. These countries have used the increased capacity and transactional experience in handling these partnerships to develop their PPP markets.

The Republic of Korea started pushing for PPP during the early 1990s to encourage private sector participation in infrastructure investment with the enactment of the Act on Promotion of Private Capital Investment in Social Overhead Capital in 1994 (ADB and KDI 2011). In 1998, the government adopted a new PPP law when financial crisis hit the Korean economy. Since then, PPP has become one of the well-established procurement modes for many types of infrastructure and public facilities in the Republic of Korea. The 2014 Infrascope (EIU 2015), which assesses the environment of PPP in the Asia and Pacific region, classified the Republic of Korea as one of the developed PPP markets in terms of readiness. Similar to the Republic of Korea, the Philippine government has recognized the vital role of the private sector to provide needed investment and lawmakers enacted two primary laws to facilitate and implement PPP infrastructure (PPP Center 2012). It has one of the oldest build-operate-transfer (BOT) policies in the Asia and Pacific region and, with subsequent amendments, positioned the Philippines with the most improved regulatory and institutional framework according to 2014 Infrascope. On the other hand, Indonesia's PPP market is emerging, although it has undertaken reforms to strengthen the institutional framework for these partnerships, improve risk sharing, and increase the use of PPPs to provide infrastructure services. Indonesia is one of the top 10 economies with improved institutional frameworks.

\footnotetext{
ADB estimate for 25 economies with adequate data, comprising $96 \%$ of the region's population.
} 
Legal and regulatory frameworks that are clear and function well are necessary for countries using PPPs as a financing modality to build and upgrade its infrastructure. This paper examines the legal and institutional frameworks as well as implementation processes for solicited and unsolicited project proposals for infrastructure PPPs in the three countries. It also looks at the main agencies and supporting organizations working on these partnerships and shows how each government provides support for a project to be financially and economically viable. A comparative analysis is then conducted to draw lessons for other economies in developing Asia seeking to improve the efficiency and effectiveness of their PPPs. The analysis underscores how strong institutions, unified procurement frameworks, and effective dispute resolution mechanisms can improve the implementation of infrastructure PPPs.

The remainder of the paper is organized as follows. Section II looks at the legal and regulatory frameworks for the three country case studies. Section III outlines the PPP implementation process of solicited and unsolicited projects for the selected countries. Section IV presents their PPP institutional frameworks. Key agencies including government organizations, and PPP centers and committees are described. Section $\vee$ shows how the three countries' governments provide support for attracting private participation. Section VI illustrates a comparative analysis of the PPP system to draw recommendations for other developing Asian economies. The last section provides a summary and conclusions.

\section{LEGAL AND REGULATORY FRAMEWORK}

Well-functioning and transparent legal and regulatory frameworks are indispensable component for countries promoting PPPs as a financing modality to build and upgrade infrastructure. Not all countries that have embarked on the PPP path have specific PPP laws, but some kind of enabling legislation is needed for the private sector to participate in public infrastructure projects, and for setting regulations for various PPP procurements. The following looks at these processes for the three country case studies. The Republic of Korea and the Philippines has one of the most comprehensive national PPP policy frameworks while Indonesia continues to evolve toward better framework and coordinated approach for PPP.

\section{A. Republic of Korea}

There are essentially two legal foundations governing PPPs in the Republic of Korea. The PublicPrivate Partnerships in Infrastructure Act of 1994 (henceforth PPP Act) is the basic law for these partnerships, and the Ministry of Economy and Finance's yearly PPP master plan suggests policy directions for the PPP system and infrastructure investments. The PPP master plan also gives general guidelines and set out project implementation procedures. More detailed guidelines are issued by the Public and Private Infrastructure Investment Management Center (PIMAC), an independent organization. To ensure transparency, PIMAC, after consulting with the Ministry of Economy and Finance, announces guidelines for carrying out each facet of a PPP project.

The two types of procurement methods in the Republic of Korea depend on whether the ownership of infrastructure will be transferred to the central government or to a local government on the completion of a PPP project. The first type, known as revertible facilities, are BOT, build-transferoperate (BTO), and build-transfer-lease (BTL) projects. The second type, nonrevertible facilities, are for build-own-operate (BOO) projects. Procurement methods are divided into how concessionaires recover their investment. BTOs, BOTs, and $\mathrm{BOOs}$ allow concessionaires to directly collect fees from 
infrastructure users, while BTLs allow them to do this through the government. For the direct collection of user fees, PPP procurement methods are divided into whether concessionaires get them from management and operation rights (BTO) or from facility owners (BOT and BOO). The PPP Act is flexible in also allowing for other procurement methods. Solicited and unsolicited project proposals are used, and these are discussed later in the paper for all three countries.

The PPP Act uses a positive list system for different types of infrastructure eligible for PPPs. The Republic of Korea appears to have adopted this system for its ability to ensure predictability and legal stability by clearly stating the scope of the Act's application for PPP projects. Here, the Act grants concessionaires a special exemption from public law by fully recognizing them as the main agents for procuring infrastructure facilities. It also endows concessionaires with powerful rights, including acquisition rights to private land.

\section{B. Philippines}

The Philippines has three legal bases for implementing PPP projects. First, the Build-Operate-Transfer Law of 1994 (Republic Act No. 6957 as amended by Republic Act No. 7718) mandates the state to provide the enabling environment and incentives for private participation in infrastructure and development projects. Executive Order No. 423 of 2005 provides guidelines on joint ventures for government-owned and controlled corporations. Under the law, public utility PPPs must be operated by Filipino entities, and if a project is a corporation, it must be at least $60 \%$ owned by Filipinos. The Local Government Code of 1991 (Republic Act No. 7160) can be used by local government units as alternative legal basis for PPPs at the local level.

The Build-Operate-Transfer Law provides for nine contractual arrangements: BOT, BTO, $\mathrm{BOO}$, build-and-transfer, build-lease-transfer, contract-add-operate, develop-operate-transfer, rehabilitate-operate-transfer, and rehabilitate-own-operate. Other arrangements can qualify as a procurement type under the law if approved by the President. Implementing agencies may accept unsolicited proposals for PPP projects on a negotiated basis if certain conditions are met.

Building and upgrading infrastructure of the eligible project, its financing, and operation and maintenance can be wholly or partly financed by the private sector in the Philippines. Other infrastructure projects authorized by government agencies may be proposed under the BuildOperate-Transfer Law. But these must have a cost-recovery component covering at least $50 \%$ of the project cost or a level determined by the approving body.

\section{Indonesia}

Indonesia's first general PPP regulation, Presidential Decree No. 7 of 1988, covered the cooperation between the government and the private sector to develop or manage infrastructure. A cross-sector regulatory framework for implementing PPPs was established in 2015 with Presidential Regulation No. 38. This stipulates that PPPs for infrastructure are determined by the head of a ministry or local government, state-owned enterprises, and enterprises owned by local governments.

Most infrastructure PPPs in Indonesia are carried out by BOTs and BOOs, though designbuild-operate, design-build-lease, and build-buy-operate are used to a lesser extent. PPP projects may be developed on a solicited or unsolicited basis, but in all cases, the selection of a private sector partner must be conducted by open tender. 
Companies providing infrastructure must, under Indonesia's PPP eligibility criteria, have the technical capacity to be able to work in the project sector concerned and deliver projects that are economically feasible and financially viable. Companies must have the financial capacity to be able to participate in an infrastructure PPP and prepare a feasibility study for the proposed PPP project. Three compensation options are available for a prospective private partner doing this: (i) extra points within $10 \%$ of the total evaluation points upon the review of the proposal assessment, ${ }^{2}$ (ii) granting the right to make a revised proposal within 30 days under the results of the assessment of the tender process, and (iii) buying the intellectual property rights of the project from the initiator.

\section{PUBLIC-PRIVATE PARTNERSHIP IMPLEMENTATION PROCESSES}

This section examines the implementation processes of solicited and unsolicited project proposals in the three countries. Indonesia and the Philippines deal with solicited PPP projects separately from public-procured projects while the Republic of Korea has a unified framework for PPPs and publicprocured infrastructure projects. All three countries encourage unsolicited PPP proposals and provide legal bases for their procurement procedure.

\section{A. Republic of Korea}

\section{Solicited Projects}

The competent authority develops a PPP project plan setting out the investment priorities and project characteristics. The PPP master plans lays out the general principles for selecting PPP projects. A candidate project must fall under one of the 59 infrastructure types covered by the PPP Act. At this stage, the competent authority assesses a candidate project's profitability, benefit to the public, user affordability, and efficiency gains, and assesses whether it is in line with national medium- and longterm infrastructure plans. A preliminary feasibility study, conducted by PIMAC, must be done if a candidate project costs exceed W50 billion ( $\$ 50$ million) or if it requires a government subsidy of over W30 billion ( $\$ 30$ million).

Once the project is designated, the competent authority puts out a request for proposal (RFP) within 1 year of a project being designated. Before the announcement is made, it is important for the authority to consult with government agencies on any issues and regulations that may affect the project once it gets going. The Public-Private Partnership Review Committee must review the RFP documents before a formal announcement is made for projects costing over W200 billion ( $\$ 200$ million) or requiring a government subsidy of over W30 million ( $\$ 30$ million).

Bidders submit project proposals to the competent authority in accordance with legislation and regulations covering this process, and they usually form a consortium of builders, maintenance operators, and financial institutions. Bidders have the right to request clarifications on any aspect of the RFP's specifications, and the competent authority must share its response with all bidders.

The competent authority forms a team of external experts to evaluate the bids using the RFP criteria. This is usually done in two stages: a prequalification evaluation of the bidder's project

2 In the Republic of Korea, based on the merits of the initial proposal, extra points within $10 \%$ of the total evaluation points can be awarded after review of the value-for-money assessment. The rate of extra points is included in the request for proposal (RFP). 
implementation capacity and a technical and financial evaluation of the proposal. The competent authority should select at least two potential concessionaires in case negotiations fail with the preferred bidder. The authority then starts negotiations with the preferred bidder, and it is usual to form a team of external legal, financial, and engineering experts for this (PIMAC can be asked to provide advisory support).

The concessionaire puts together a detailed engineering and design plan-based on the PPP contract - for the project and applies for the plan's approval within 1 year of the project being awarded. The competent authority notifies the concessionaire of its decision on the engineering and design plan within 3 months from the application's filing date. Once the plan is approved, the concessionaire is responsible for getting all the permits and approvals for construction. The competent authority monitors construction to ensure the quality of the building materials and the equipment used. An independent expert is usually hired to do this.

\section{Unsolicited Proposals}

The competent authority reviews unsolicited project proposals to ensure they are in line with the government's infrastructure investment plans and priorities, and for their commercial viability. PIMAC's review of these project proposals entails a value-for-money analysis, which has three phases: (i) a cost-benefit and policy analysis; (ii) a comparative analysis between a public sector comparator and the PPP proposal; and (iii) a financial analysis to assess the project cost, user fees, and level of government financial support. PIMAC submits its review to the competent authority and the Ministry of Economy and Finance.

When pursuing an unsolicited project, the competent authority must notify the public about the content of the proposal to allow other parties to submit alternate proposals, and at least 90 days is allocated for this to ensure fair competition. Based on the merits of the initial proposal, extra points within $10 \%$ of the total evaluation points can be awarded after the review of the value-for-money assessment. ${ }^{3}$ The rate of extra points is included in the RFP (Kim et al. 2011).

The competent authority's evaluation team assesses the alternative proposals, including the initial proposal again, and selects a preferred bidder. If no other alternate proposals are submitted, the initial bidder is designated as the potential concessionaire for the PPP negotiation phase.

\section{B. Philippines}

\section{Solicited Projects}

A PPP project initiated by the government covers four stages: project identification and prioritization, project approval, project procurement, and contract award. In the first phase, the project is assessed to ensure that it supports the Philippine Development Plan and sector master plans. Candidate projects are then included in the Comprehensive and Integrated Infrastructure Program, which accompanies the Philippine Development Plan. Both are approved by the board of the National Economic and Development Authority (NEDA), the government's central planning agency, and are reviewed annually.

3 The competent authority may grant preference points to the initial proponent of a project, taking into consideration the ratio of preference points recommended by PIMAC based on the value-for-money testing report. The preference points are within the limit of $10 \%$ of total points of evaluation. 
Preparing an infrastructure PPP project begins with the implementing agency conducting prefeasibility analysis. Detailed feasibility studies are then conducted on viable projects. The results determine the type and level of government support; for example, viability-gap funding. Although there are no multiyear appropriations, government agencies handling infrastructure projects are required to submit a 3-year rolling plan on their proposed priority infrastructure investments to the Department of Budget and Management. Before a project can be included in an implementing agency's budget request, approvals from various government bodies are required; these are set out in Table 1.

Table 1: Approval Procedures for Public-Private Partnership in the Philippines

\begin{tabular}{lll}
\hline Implementing Agencies & \multicolumn{1}{c}{ Approving Body } & \multicolumn{1}{c}{ Approval Thresholds } \\
\hline National government agencies & $\begin{array}{l}\text { Investment Coordination Committee } \\
(\text { ICC) }\end{array}$ & Up to P300 million (\$6 million) \\
& $\begin{array}{l}\text { National Economic and Development } \\
\text { Authority Board (on ICC's } \\
\text { recommendation) }\end{array}$ & $\begin{array}{l}\text { Above P300 million and for all negotiated } \\
\text { projects (e.g., unsolicited proposals) }\end{array}$ \\
\hline Local government units & Municipal Development Council & Up to P20 million (\$0.4 million) \\
& Provincial Development Council & Above P20 million to P50 million (\$1 million) \\
& City Development Council & Up to P50 million \\
& Regional Development Council & $\begin{array}{l}\text { Above P50 million up to P200 million } \\
\text { (\$4 million) }\end{array}$ \\
& ICC & Above P200 million \\
\hline
\end{tabular}

Source: Korea Development Institute. 2015. A Comparison Study on PPP System of Korea, Philippines and Indonesia. Sejong.

The next step is to get the approval of government oversight bodies. The Investment Coordinating Committee, which is made of up NEDA officials, evaluates the project's alignment with and contribution to the Philippine Development Plan. The Department of Finance appraises project risk, allocates the fiscal requirements and government debt needed to carry it out, and estimates the financial internal rate of return. It also evaluates the project's impact on fiscal sustainability by assessing the government's direct, contingent, and opportunity costs. The Public-Private Partnership Center of the Philippines (henceforth PPP Center), the main support organization for PPPs, and a NEDA agency conducts value-for-money and financial analyses and validates the appropriateness of viability gap funding.

The approval of these oversight bodies is a prerequisite to government budget support for PPP projects and for the project tender itself. Competitive bidding is the default mode for project procurement and awarding contracts in the Philippines. Negotiated contracts are allowed if there is only one complying bidder in a competitive bid, but these are restricted to the financial proposal. The head of the implementing agency is authorized to sign the contract after it has been reviewed by the agency's legal counsel. Department of Finance approval is needed for projects in which the national government has direct and contingent liability. Figure 1 shows the procurement process options for solicited PPP proposals. 
Figure 1: Public-Private Partnership Procurement Process Options for Solicited Proposals

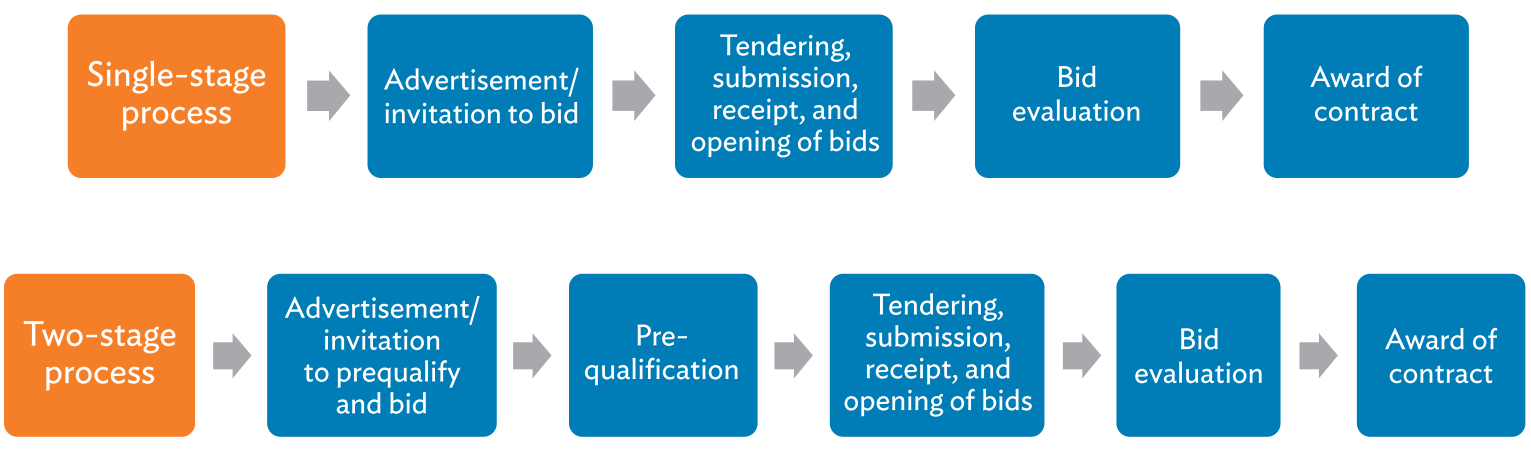

Source: Public-Private Partnership Center of the Philippines. 2014. National Government Agency Public-Private Partnership Manual. Manila.

\section{Unsolicited Proposals}

Implementing agencies may accept unsolicited proposals for a PPP project on a negotiated basis if three conditions are met. First, the project has a new concept or technology that is approved by the implementing agency and is not on the list of national or local priority projects. Second, the project does not require a government guarantee, subsidy, or equity stake. And third, the implementing agency puts an announcement in a newspaper detailing the comparative or competitive proposal; here, challengers have 60 working days to submit a comparative proposal. If no complying proposals are received, the original proponent is awarded the contract. If a challenger submits a better price proposal than the one submitted by the original proponent, the proponent has the right to match within 30 working days after receiving the bid results. Should the original proponent fail to match the challenger's price proposal within this period, the contract is awarded to the challenger. But if the original proponent matches the price proposal of the comparative proponent within this period, the project is awarded to the original proponent. All negotiated PPP contracts require the approval of NEDA's board, which bases its decision on the recommendation of the Investment Coordination Committee.

\section{Indonesia}

\section{Solicited Projects}

The process for government solicited infrastructure PPP projects in Indonesia has four phases: planning, preparation, transaction, and contract management. In the first phase, the government contracting agency identifies potential projects for private sector participation in accordance with government policies and objectives for infrastructure, and in terms of the available resources and project timing. The contracting agency then assesses the potential project's priority, using the following criteria:

(i) clarity of the PPP project's description,

(ii) obstacles to using the main resources for implementing the project,

(iii) clarity of the results of the project's inputs,

(iv) social and environmental impacts,

(v) potential for sustainable demand, 
(vi) ease of land acquisition and resettlement,

(vii) government's ability to support the project,

(viii) institutional readiness, and

(ix) whether the project is included in the government's strategic priorities and planning for infrastructure.

In the project preparation phase, the government contracting agency studies possible risks for a project being a PPP, and the project's social benefits. This phase has two steps: the first outlines the case to be made for the project as a business proposition. Here, a legal and technical assessment of the project, and a prefeasibility study, are carried out. A preparation-of-readiness study is drawn up in the second step, focusing on the availability of land. The contracting agency prepares a list of land compensation or expropriation that defines the land needed for the project.

The transaction phase covers procurement planning and implementation. Here, the government contracting agency completes the prefeasibility study and prepares the procurement plan for public tender. The contracting agency then forms a procurement committee of experts, which arranges a procurement schedule and a procurement-notices concept. In this phase, the agency sounds out investor interest to present an attractive project package to potential investors. The committee also prepares a self-estimated price for the project, and the prequalification and procurement documents. A winning bidder is then selected using the procurement steps shown in Figure 2.

Figure 2: Public-Private Partnership Procurement Process for Solicited Proposals

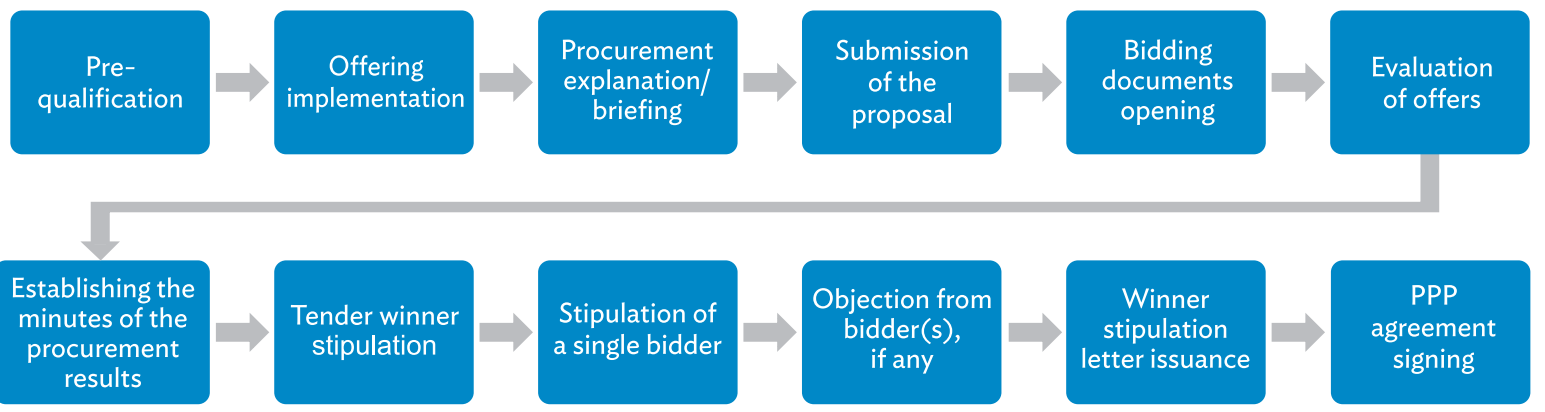

PPP = public-private partnership.

Source: National Development Planning Agency. 2015. Public Private Partnerships. Infrastructure Projects Plan in Indonesia 2015. Jakarta.

\section{Unsolicited Project}

Unsolicited project proposals for PPPs in Indonesia have two stages. The first covers the time from when a project proponent presents a project to the government until all internal assessments and approvals are finished and the project is ready to be tendered. The second stage is a competitive tender, which may well differ in the incentives or benefits in the project proponent's unsolicited proposal.

In the first stage, the first step, to get a project approved for an unsolicited proposal, begins with a letter of intent proposing the project and a concept suggestion (and includes documentation showing the proponent is able to carry out the project). The contracting agency decides whether to continue with the proposal. The second step involves the contracting agency's evaluation of the project proponent's 
feasibility study and whether the proponent fulfills the requirements to join the tender. Three things need to be done for this: (i) the proponent submits the feasibility documents to the contracting agency, (ii) the agency evaluates and assesses the feasibility study and prequalification requirements, and (iii) the agency approves or rejects the proposal. The third step is the process to get the contracting agency's approval for the project proponent to be formally designated as the project's initiator.

Compensation is provided in the following forms in the second stage: (i) extra points within $10 \%$ of the total evaluation points upon the review of the proposal assessment to the project proponent; (ii) granting the proponent the right to make a revised PPP project proposal no later than 30 days from the announcement of the best offer in the tender process; and (iii) in the event of a project proponent getting additional evaluation point or the right to match, transfer of ownership of the feasibility study and other project documents to the contracting agency. If the project proposal is bought from the proponent, the proponent is prohibited from joining the tender.

\section{PUBLIC-PRIVATE PARTNERSHIP INSTITUTIONAL FRAMEWORKS}

Although legal and regulatory frameworks enable PPPs, a second tier of institutions and processes is needed to implement applicable laws, regulations, rules, and policies. Well-functioning institutional arrangements are essential for this process going smoothly. Without them, PPPs will be harder to develop-and the agencies with specific responsibilities under legislation to implement PPPs may not function effectively. Governments have established specialized PPP units to develop and supervise projects and these units play a vital role in successfully promoting and developing PPP projects.

\section{A. Republic of Korea}

The competent authority in the Republic of Korea is the head of the central administrative agency responsible for an infrastructure PPP project. If the project is a national one, the competent authority is a central government ministry. If the project is a regional one, it is the head of the relevant local government. This is also the case if the project is subsidized by the central government but implemented by a local government. Table 2 presents the key agencies promoting PPP systems.

\section{Table 2: Government Organizations Promoting Public-Private Partnership Systems in the Republic of Korea}

\begin{tabular}{ll}
\hline Key Agencies & \multicolumn{1}{c}{ Function } \\
\hline $\begin{array}{l}\text { Ministry of Economy and Finance } \\
\text { (Fiscal Management Bureau) }\end{array}$ & $\begin{array}{l}\text { The ministry oversees general fiscal management and has two primary } \\
\text { tasks: (i) to formulate mid- to long-term fiscal strategies and a roadmap } \\
\text { for fiscal consolidation, (ii) and to manage budget spending and assess } \\
\text { fiscal performance to improve fiscal effectiveness. }\end{array}$ \\
\hline $\begin{array}{l}\text { Public and Private Infrastructure Investment } \\
\text { Management Center (PIMAC) }\end{array}$ & $\begin{array}{l}\text { Responsible for supporting public-private partnership (PPP) projects } \\
\text { implemented by the private sector and competent authorities under } \\
\text { the PPP Act. PIMAC provides the feasibility analysis of large-scale } \\
\text { projects, and the evaluation of project plans. }\end{array}$ \\
\hline
\end{tabular}

Source: Authors' compilation.

Under the PPP Act, the Public-Private Partnership Review Committee was established as a unit under the Ministry of Economy and Finance to oversee policies and decisions affecting large-scale PPP projects. The government amended the PPP Act in 2011 to establish the Committee for Mediation 
of Public-Private Partnership Project Disputes under the direct jurisdiction of the minister of strategy and finance.

\section{B. Philippines}

Several types of institutions play a major role in the Philippines' PPP program. Implementing agencies sponsor the development of PPP projects; these agencies are made up of government departments; subnational agencies, particularly local government units; and government-owned and controlled corporations (Table 3). These agencies work together to ensure better collaboration between the private sector and government.

\section{Table 3: Government Organizations Promoting Public-Private Partnership Systems in the Philippines}

\begin{tabular}{|c|c|}
\hline Key Agencies & Function \\
\hline Department of Finance & $\begin{array}{l}\text { Approves government undertakings, direct and contingent; approves } \\
\text { public-private partnership (PPP) contracts requiring government } \\
\text { undertakings, including access to official development assistance loans and } \\
\text { sovereign guarantees. }\end{array}$ \\
\hline $\begin{array}{l}\text { National Economic and Development } \\
\text { Authority (NEDA) }\end{array}$ & $\begin{array}{l}\text { Constitutional body tasked with formulating the Philippines' strategic } \\
\text { socioeconomic development plan, and coordinating the prioritization of the } \\
\text { plan's investment program, which is funded from public and private } \\
\text { resources through PPPs. }\end{array}$ \\
\hline Investment Coordination Committee & $\begin{array}{l}\text { Evaluates the fiscal, monetary, and balance-of-payment implications of } \\
\text { major national projects. }\end{array}$ \\
\hline $\begin{array}{l}\text { Development Budget Coordinating } \\
\text { Committee }\end{array}$ & $\begin{array}{l}\text { Advises annual government expenditure program, and the ceiling of } \\
\text { government spending for economic and social development, defense, and } \\
\text { debt servicing. }\end{array}$ \\
\hline Infrastructure Committee & $\begin{array}{l}\text { Advises on infrastructure policies on their consistency with national } \\
\text { development goals, coordinates the preparation of infrastructure programs, } \\
\text { strategic investment programs, and the project plans of government } \\
\text { infrastructure agencies. }\end{array}$ \\
\hline PPP Center & $\begin{array}{l}\text { Is mandated to facilitate the implementation of PPP programs and project. } \\
\text { The center was reorganized under Executive Order No. } 8 \text { in } 2010 \text { and serves } \\
\text { as the central coordinating and monitoring agency for all PPP projects in the } \\
\text { Philippines. }\end{array}$ \\
\hline
\end{tabular}

Source: Authors' compilation.

\section{Indonesia}

Infrastructure investments and development are demarcated by sector in Indonesia. Because each sector has its own laws and regulations, coordination is essential for effective infrastructure development. Indonesia established several key agencies implementing and promoting PPP (Table 4) but if responsibilities are not clearly defined and with overlapping functions, these might create coordination problems (ADB 2017a). 
Table 4: Government Organizations Promoting Public-Private Partnership Systems in Indonesia

\begin{tabular}{|c|c|}
\hline Key Agencies & Function \\
\hline $\begin{array}{l}\text { Ministry of National Development Planning } \\
\text { and National Development Planning Agency } \\
\text { (BAPPENAS) }\end{array}$ & $\begin{array}{l}\text { Coordinates the public-private partnership (PPP) program; decides whether } \\
\text { projects should be procured as PPPs and evaluates progress on PPP projects. } \\
\text { BAPPENAS has a central PPP unit, the Directorate, responsible for ensuring } \\
\text { policy consistency, quality control and transparency, setting standards, and } \\
\text { compliance monitoring for PPP projects }\end{array}$ \\
\hline $\begin{array}{l}\text { Committee of Infrastructure Priorities } \\
\text { Development Acceleration }\end{array}$ & $\begin{array}{l}\text { Recommends policies to strengthen the PPP system, and determines the } \\
\text { priority of PPP projects }\end{array}$ \\
\hline Ministry of Finance & Provides budgets for PPPs and recommends fiscal support for PPP projects \\
\hline PT Sarana Multi Infrastruktur (SMI) & State-owned enterprise provides infrastructure financing for PPP projects \\
\hline State Asset Management Agency & Providing land acquisition fund in infrastructure delivery \\
\hline Indonesia Infrastructure Guarantee Fund & $\begin{array}{l}\text { Mandated to provide contingency support and guarantee to risks, such as } \\
\text { delays on the part of the government for getting projects off the ground }\end{array}$ \\
\hline $\begin{array}{l}\text { The State-Owned Infrastructure Financing } \\
\text { Company }\end{array}$ & $\begin{array}{l}\text { Indonesia's other main supporting agency for PPPs, and its mandate is to } \\
\text { provide alternative sources of funds to finance projects, promote and } \\
\text { support PPPs, and to increase the size, capacity, and effectiveness of } \\
\text { infrastructure projects through partnerships with third parties }\end{array}$ \\
\hline
\end{tabular}

Source: Authors' compilation.

\section{GOVERNMENT SUPPORT FOR PUBLIC-PRIVATE PARTNERSHIPS}

Governments will only attract private participation in infrastructure if investors are confident of earning a reasonable return. For countries that do not have mature PPP markets, investors also want government support or guarantees for a certain degree of risk-and governments can improve the bankability of projects by using support instruments such as equity, debt relief, grants, guarantees, fiscal incentives, and contract clauses based on project needs.

The Republic of Korea provides financial support through subsidy to resolve financial feasibility problems that may occur while viability gap funding is available for infrastructure PPPs in the Philippines and Indonesia.

\section{A. Republic of Korea}

The Korean government has provided a range of administrative and financial support as part of its effort to promote PPP projects.

\section{Construction Subsidy}

If it is necessary to set user fees for infrastructure at a certain level, the government may, under the PPP Act, give a construction subsidy to a concessionaire. The amount is determined in the concession agreement and the ratio of subsidy to construction costs is decided by negotiation. The timing for subsidy payments is determined in the concession agreement and is set in terms of the concessionaire's equity investment plan. Construction subsidies are paid annually or quarterly and cannot be concentrated in a particular year. The point of distribution must reflect the progress being made on completing a project, and the scope of the equity investment. 


\section{Risk-Sharing System}

Two risk-sharing schemes for BTO projects were introduced in 2015 to reinvigorate this modalityBTO risk-sharing project scheme and BTO-adjusted project scheme. Under a BTO risk-sharing project scheme, investment and operating costs are shared by the government and the private partner at a certain ratio, and both share excess profits or losses (Figure 3 ). If the share of investment cost between government and private is 50:50, the private can receive a certain portion of the operating costs from the government when the demand is not sufficient (Example 1), but when the demand is exceeded, the government can have a partial return of the private profits (Example 2). The fundamental concept of BTO risk-sharing is that the competent authority shares a portion of the private sector's investment risk rather than the revenue risk. It would be a way to lower the rate of return of the part of the government investment and ultimately to lower the user fees.

BTO risk-sharing was introduced to supplement the previous system in which the private sector took on most of the project risk for a BTO project, and the government took on most of the risk for a BTL project. Under this scheme, private partners bear less revenue risks, compared with standard BTO scheme.

\section{Figure 3: Mechanism of a Build-Transfer- Operate Risk-Sharing Scheme} in the Republic of Korea
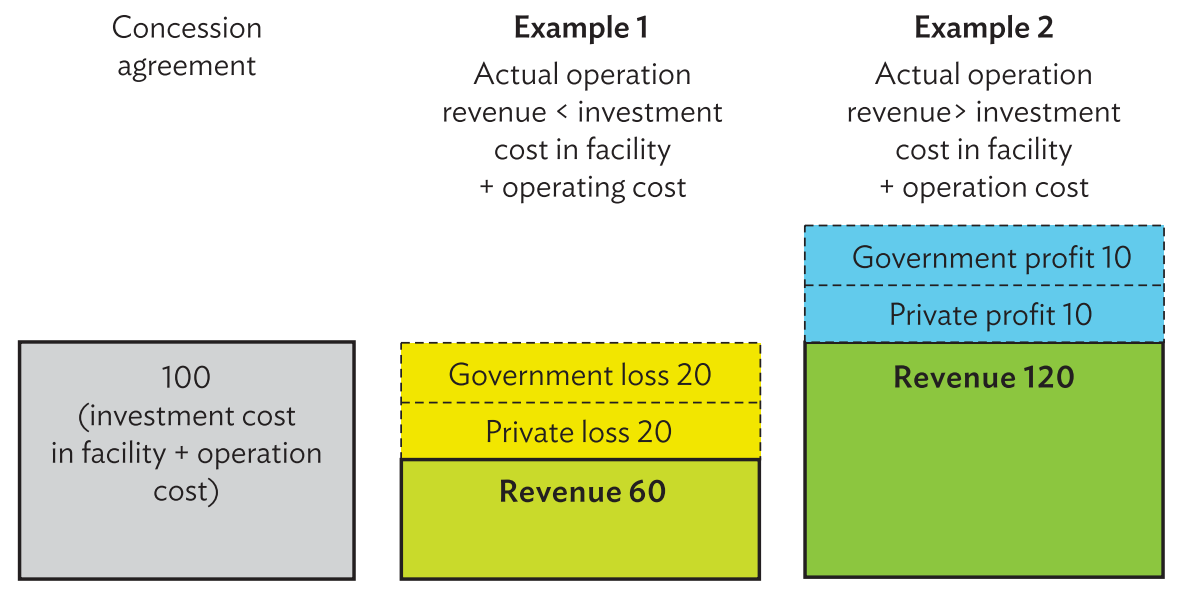

Note: If the share of investment risks between government and private is 50:50

Source: Ministry of Strategy and Finance. 2015. Public-Private Partnership Projects Promotion Plan. Sejong.

Under a BTO-adjusted PPP project scheme, the government covers the repayment of the principal loan of $70 \%$ and the interest for $30 \%$ of the total private investment (Figure 4 ). In addition, when excess profits occur, it can be shared by the government and concessionaire at the 7:3 ratio (Example 3). The concessionaire bears a loss for as long as it is less than $30 \%$ of the total private investment. If the loss exceeds $30 \%$, the concessionaire receives government financial support (Example 1). It is a method to lower the private risk by the government as much as the minimum operation cost necessary to finance and operate the facility. The advantage of this system is that it can reduce project risk for the private partner and user fees. BTO-adjusted PPP projects are especially useful for environmental infrastructure, such as sewage and wastewater disposal. 
Figure 4: Mechanism of a Build-Transfer-Operate-Adjusted Scheme in the Republic of Korea

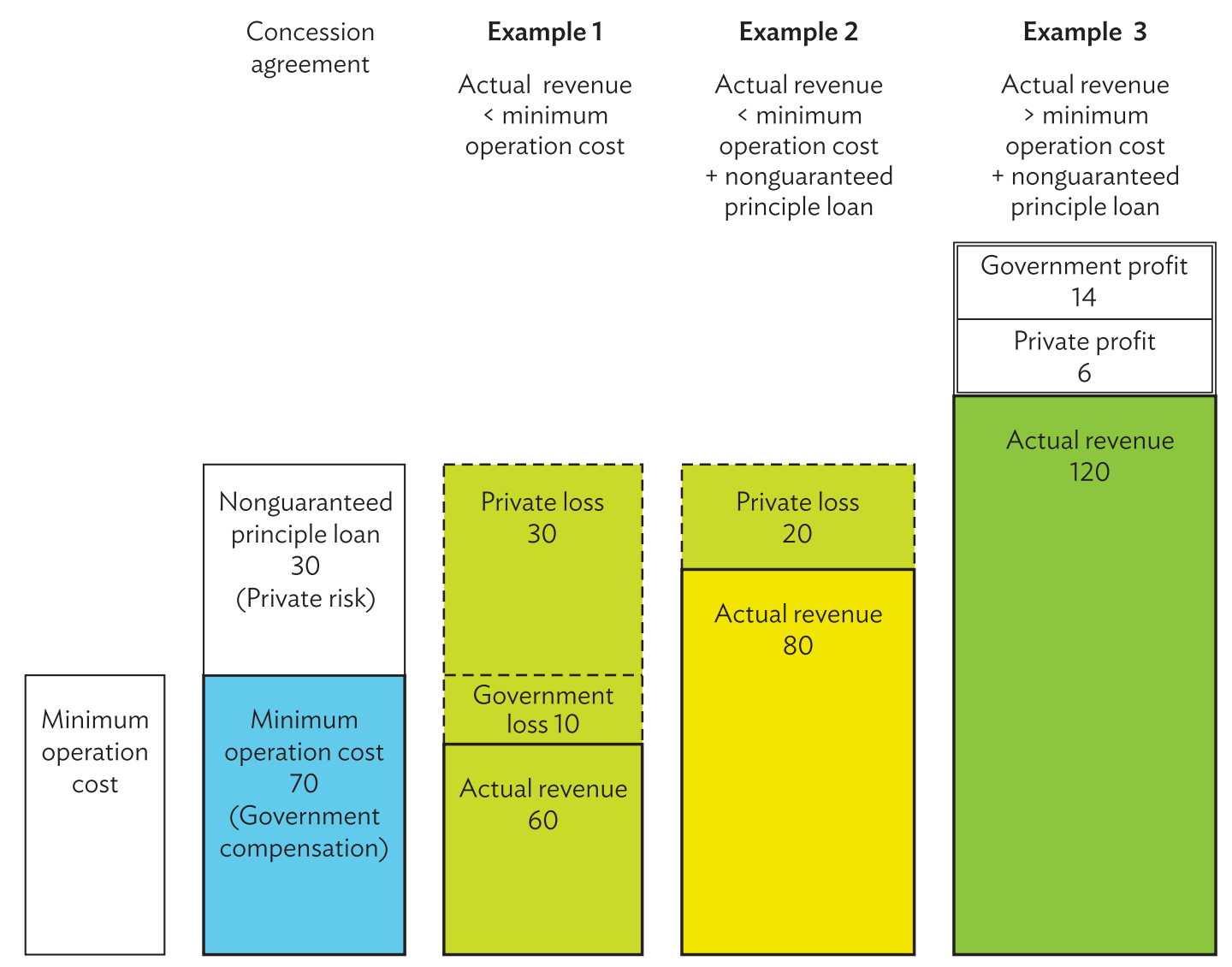

Source: Ministry of Strategy and Finance. 2015. Public-Private Partnership Projects Promotion Plan. Sejong.

\section{Credit Guarantee}

Since 1994, the Infrastructure Credit Guarantee Fund has provided credit guarantees to concessionaires borrowing from financial institutions for PPP projects. Under the PPP Act, the fund is managed by the Korea Credit Guarantee Fund, a public financial institution that extends credit guarantees for the liabilities of promising enterprises which lack tangible collateral. The Infrastructure Credit Guarantee Fund is financed through annual government investment, revenue from guarantee fees, and returns on investments. When a fund-guaranteed project defaults, the fund subrogates on behalf of the concessionaire. If a project guaranteed by the fund becomes bankrupt, the fund reimburses the concessionaire for its obligations. The credit guarantee limit for each project is W300 billion ( $\$ 300$ million), and the maximum annual guarantee fee is $1.5 \%$ of guaranteed fund.

\section{Buyout Right}

Concessionaires of revertible infrastructure facilities may request the central or local government to buy out these facilities, including supplementary ones, if they are unable to build, manage, or operate them because of unavoidable circumstances due to a force majeure. 


\section{Compensation on Termination}

The possibility of compensation in the case of premature contract termination is a significant risk mitigation factor for concessionaires, enabling them to finance debt at favorable interest rates. If a concessionaire is unable to maintain a facility, a request can be made to the government to terminate the concession agreement. If this happens, the government assumes the management and operation rights of the facility. The method of calculating payment and the causes for termination must be specified in the concession agreement.

\section{Exemption from Charges and Taxes}

The central or a local government may exempt a PPP project fully or partially from certain taxes. Table 5 gives the details.

\section{Table 5: Exemption from Charges and Taxes for Public-Private Partnership Projects in the Republic of Korea}

\begin{tabular}{|c|c|}
\hline Relevant Acts & Details of Exemption \\
\hline $\begin{array}{l}\text { Farmland Act, Management of } \\
\text { Mountainous Districts Act }\end{array}$ & $\begin{array}{l}\text { A facility installed for a public-private partnership (PPP) project may be exempted } \\
\text { fully or by } 50 \% \text { from the farmland conservation charge and the substitute forest } \\
\text { development cost. }\end{array}$ \\
\hline \multirow[t]{4}{*}{ Restriction of Special Taxation Act } & $\begin{array}{l}\text { A concessionaire is permitted to issue social overhead capital bonds for implementing } \\
\text { a PPP project, and a separate tax rate of } 14 \% \text { is applied to the interest income from } \\
\text { the bonds. Effective until } 31 \text { December } 2018 \text {. }\end{array}$ \\
\hline & $\begin{array}{l}\text { A zero-tax rate is applied to the value-added tax on an infrastructure facility or for } \\
\text { construction services, which the concessionaire supplies to the central or local } \\
\text { government. Effective until } 31 \text { December } 2018 \text {. }\end{array}$ \\
\hline & $\begin{array}{l}\text { A zero tax is applied to the value-added tax on urban railroad construction services } \\
\text { supplied directly by the concessionaire. Effective until } 31 \text { December } 2018 \text {. }\end{array}$ \\
\hline & $\begin{array}{l}\text { A foreign investment of at least } \$ 10 \text { million in a PPP facility installed in a foreign investment } \\
\text { zone is exempt from the corporate, income, acquisition, registration, and property tax. }\end{array}$ \\
\hline \multirow[t]{4}{*}{ Corporate Tax Act } & $\begin{array}{l}\text { An allowance for writing off indemnity receivables is recognized as a loss on the Infrastructure } \\
\text { Credit Guarantee Fund under the Public-Private Partnerships in Infrastructure Act. }\end{array}$ \\
\hline & $\begin{array}{l}\text { Where a domestic corporation spends a subsidy or other asset received for implementing } \\
\text { a PPP project to acquire or ameliorate an asset for the project, the equivalent amount may } \\
\text { be included in losses in calculating the income for the applicable fiscal year. }\end{array}$ \\
\hline & $\begin{array}{l}\text { Land developed for implementing a PPP project is exempt from the additional } \\
\text { income tax for transferring the property. }\end{array}$ \\
\hline & $\begin{array}{l}\text { Where a concessionaire meets the requirements for a nominal investment } \\
\text { company under the Corporate Tax Act and distributes } 90 / 100 \text { or more of } \\
\text { distributable income as dividends, the amount of these dividends may be deducted } \\
\text { in calculating the amount of income. The requirements for a nominal investment } \\
\text { company are at least W5 billion ( } \$ 5 \text { million) for companies implementing any PPP } \\
\text { project other than a build-transfer-lease (BTL) PPP, or equity of at least W1 billion } \\
\text { ( } \$ 1 \text { million) for companies implementing a BTL PPP. }\end{array}$ \\
\hline \multirow[t]{2}{*}{ Local Tax Act } & $\begin{array}{l}\text { A corporation newly established in the Seoul Metropolitan Area for implementing a PPP } \\
\text { project is recognized as an exception to the triple taxation of the registration tax. }\end{array}$ \\
\hline & $\begin{array}{l}\text { Acquisition and registration tax are waived for a project implemented under the } \\
\text { condition that the property will revert or be donated to the central or local government. }\end{array}$ \\
\hline
\end{tabular}

Source: Ministry of Strategy and Finance. 2017. Public-Private Partnership Basic Plans. Sejong. 


\section{Land Acquisition}

Under the PPP Act, a concessionaire may have expropriation rights and can entrust the task of land purchase, compensation for losses, and the resettlement of residents, among other factors, to the competent authority or the head of a local government. A concessionaire needs to discuss with the head of the administrative agency the use of land belonging to the state or local government for a PPP project. This land may not be sold for any other purpose than for the project after the project proposal has been publicly announced.

Under the PPP Act, national or public property in areas designated for PPP projects may be sold to the concessionaire through a concession agreement. The concessionaire may use this property free of charge.

\section{B. Philippines}

Under the Build-Operate-Transfer Law, the government may provide any form of direct or indirect support for infrastructure PPP projects.

\section{Cost Sharing}

The implementing agency or local government unit bears a portion of the capital expense for a PPP infrastructure project. This is provided that viability gap funding does not exceed $50 \%$ of the project cost. Any government share of a PPP may be financed from direct government appropriations or from official development assistance.

\section{Credit Enhancements}

Direct and indirect support for an infrastructure PPP project by the project operator, the implementing agency, and local government unit is contingent on certain events or risks (natural disasters, for example) happening, as stipulated in the PPP contract. Credit enhancements are allocated to the party that is best able to manage these risks. Credit enhancements can include government guarantees on project performance, and indirect guarantees can also be offered. These are agreements in which the government or any of its agencies or local government units assume full or partial responsibility for a project's financial standing to avoid the project operator defaulting on the project loan.

\section{Direct Government Subsidy}

These are used when the government or any of its agencies or local government units (i) defray or pay for a portion of a project's cost, (ii) condone or postpone payments due from a project proponent, (iii) contribute property or assets to a project, (iv) waive or grant special rates on real property taxes on a project during the term of the contract agreement in the case of local government units, and (v) waive charges or fees for business permits or licenses needed for a project's construction.

\section{Direct Government Equity}

This involves the subscription by the government, or any of its agencies or local government units, of shares, or other securities convertible to shares, of the project company's stock. The subscription can be paid by cash or assets. 


\section{Performance Undertaking}

This is an undertaking by a government department or agency, government-owned or controlled corporation, or local government unit to assume responsibility for the performance of the obligations of the implementing agency or local government unit under the project agreement. This includes paying obligations in the event of default. These undertakings may be subject to the payment of risk premiums to the national government, local government unit, or any other authorized agency.

\section{Legal Assistance}

This is given for PPP infrastructure projects only in cases, hearings, or inquiries where the implementing agency or local government unit and the project proponent are third-party defendants and respondents.

\section{Project Development and Monitoring Fund}

The Project Development and Monitoring Fund (PDMF), set up in 2010 under Executive Order No. 8, provides government funding that implementing agencies can tap to help them identify, prioritize, and prepare PPP projects, and for related advisory services (Figure 5). Since 2010, the PDMF has supported 35 of the 53 projects in the Philippines' PPP program, with 45 out of 76 applications for PDMF funding approved. Since 2011, the fund has disbursed P2.15 billion ( $\$ 42.9$ million), according to the PPP Center, which administers the fund.

Figure 5: Project Development and Monitoring Fund Flow Chart of the Philippines

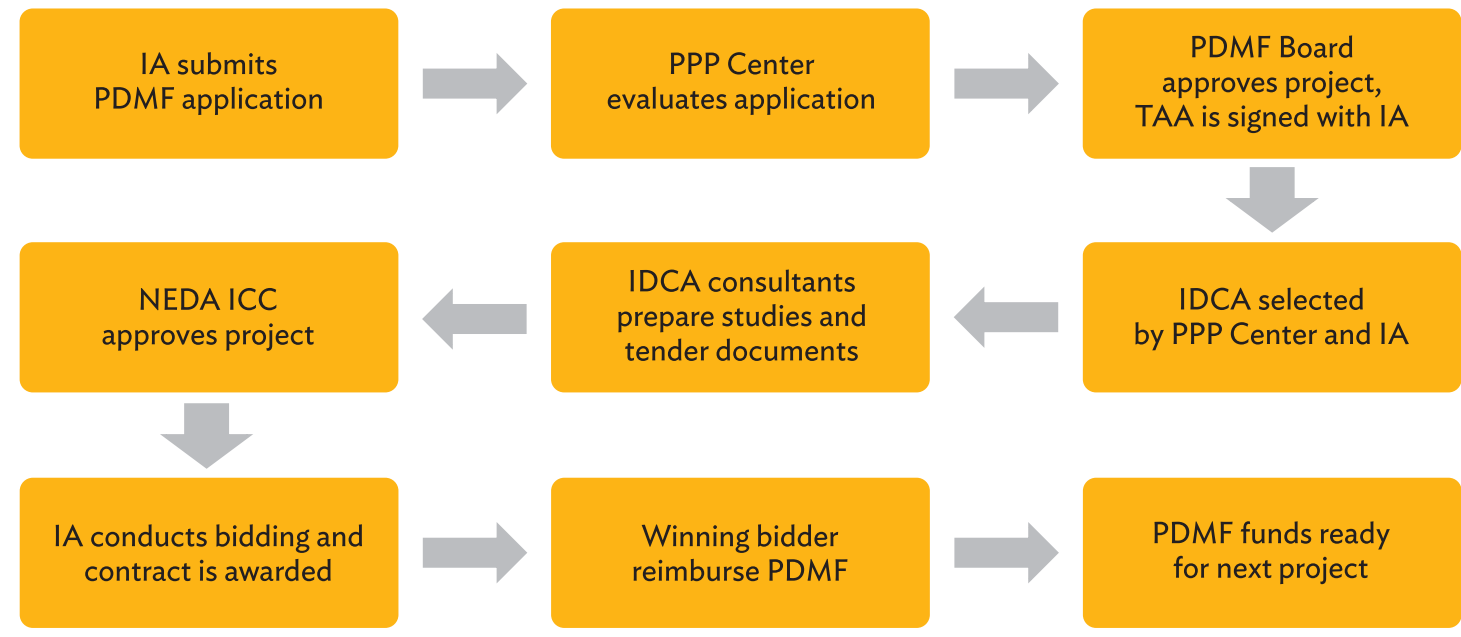

$I A=$ implementing agency, ICC = Investment Coordination Committee, IDCA = indefinite delivery contract assistance; NEDA = National Economic and Development Authority, PDMF $=$ Project Development and Monitoring Fund, PPP $=$ public-private partnership, TAA = technical assistance agreement.

Source: Public-Private Partnership Center of the Philippines. 2011. Project Development and Monitoring Facility Guidelines. Manila.

The center also assists in the deal flow of solicited PPP projects. Through the fund, it prepares business cases, prefeasibility studies, and tender documents for projects. The PDMF is financed by the Philippine government and the Australian Aid, and administered by the Asian Development Bank. By 2016, the fund stood at \$69.5 million: \$51.5 from the Philippines and \$18 million from Australia (Ricote 2016). 


\section{Public-Private Partnership Strategic Support Fund}

Like the PDMF, the Public-Private Partnership Strategic Support Fund was set up in 2010 under Executive Order No. 8. The fund is available for funding right-of-way acquisitions and related costs, such as resettlement, and costs associated with a PPP project's government-delivered components.

\section{Indonesia}

Under the relevant regulations and institutions, the government provides a form of direct and indirect support for infrastructure PPP projects.

\section{Direct Support}

The government contracting agency may contribute certain physical facilities to an infrastructure PPP project. It can also cover certain capital costs and provide operating subsidies through the annual national or regional budget; these costs are approved by national and regional parliaments. Direct support can be given when an infrastructure PPP is economically justified, but not financially feasible.

\section{Land Acquisition}

The Ministry of Finance through its State Asset Management Agency launched in 2017 a land acquisition scheme for nationally strategic infrastructure PPP projects. The agency is mandated to provide land funds for all national strategic projects to ensure timely acquisition processes and boost private investment in PPP projects.

\section{Contingent Support}

Contingent support is a government guarantee to compensate a PPP project company if a risk specified in the PPP contract happens. Here, the government guarantees the sort of risks that it is in the best position to manage-for example, political, project performance, and demand risks-and for which there is an economic justification to do so. Project performance risk includes delays in land acquisitions, rising land acquisition costs, post-contract changes in performance specifications, lowerthan-contracted tariff adjustments, and delays in operation.

To activate contingent support, the government contracting agency requests this based on feasibility study findings. The request is reviewed by the Committee of Infrastructure Priorities Development Acceleration, evaluated by the Risk Management Unit, approved by the Ministry of Finance, and administered by the Indonesia Infrastructure Guarantee Fund.

\section{Indonesia Infrastructure Guarantee Fund}

This was set up by the government in 2009 as a state-owned company to be a one-stop processor for appraising, structuring, and guaranteeing infrastructure PPPs. The fund provides guarantees to mitigate government contractual risks in PPP projects; these are basically the financial obligations of the government contracting agency. The fund manages the guarantee and processes any claims. 


\section{Tax Incentives and Viability Gap Funding}

The government, through the Ministry of Finance, may extend tax incentives to private partners for certain types of PPP projects. Viability gap funding is available for up to $50 \%$ of the construction, equipment, and installation costs of an infrastructure PPP project. It may also be used for interest payments during construction.

\section{COMPARATIVE ANALYSIS}

Infrastructure PPP projects need the support of government, the public, and all other major stakeholders to be successful. These parties have a big say in whether a PPP goes ahead in the first place, and in defining a project and monitoring service quality. Their involvement can identify early in the process potentially problematic issues that can either get overlooked or be more difficult to fix later. Independent public oversight during the implementation phase can build public trust in a project and promote public sector innovation.

Communicating national infrastructure plans with the public and end users needs improving in the three country case studies. Opposition to infrastructure PPPs in all these countries is widespread because of high user fees, poor service, the involvement of foreign investors in these projects, and the potential for corruption. Civic groups in these countries are often critical that infrastructure PPP can have adverse social and environmental impacts, particularly for minority groups.

Governments need to communicate effectively with the public and civil society on planned infrastructure PPPs. Each PPP project needs a stakeholder engagement strategy that sets out how the project will be explained to affected communities and civil society groups. None of the three countries, however, undertake such a strategy. Consultations on planned projects should be held with civil groups to be able to understand early on possible objections to elements of a project. End users should be part of this process and be used to monitor service quality once the project is completed.

\section{A. Legal and Regulatory Framework}

Overall, the legal and regulatory frameworks in the three countries are sufficiently conducive for implementing infrastructure PPPs. But there is room for improvement. Indonesia and the Philippines need to streamline their legal and regulatory procedures to be able to resolve disputes efficiently and quickly. In the Republic of Korea, the government set up the Committee for Mediation of PublicPrivate Partnership Project Disputes for this very purpose. Disputes are not unusual in PPPs since they require large investments over a long time and are susceptible to changes in business conditions and policy objectives. Being able to manage disputes is essential because they are not only costly and timeconsuming, but, if unchecked, can wreck a partnership.

Training officials at all levels working on PPPs is also needed to build the knowledge of officials in Indonesia and the Philippines on PPP rules and regulations, and ensuring these officials have a thorough understanding of and project-based concession agreements. Going by the Republic of Korea's experience, most PPP disputes are over toll fees, project costs, taxes, interpretation and application of laws, refinancing, gain sharing, and government payments. 


\section{B. Procurement Process}

For solicited projects, Indonesia and the Philippines appraise, select, budget, manage, and monitor their PPPs separately from government-procured projects. This practice, however, distorts the priorities of public investments, ignores the management of public finances, and creates undue fiscal risks which can be caused by PPP projects. To counter these problems and to help promote slackening private investment in infrastructure, the Republic of Korea, in 2015, adopted a unified framework for integrating PPPs and government-procured investment projects.

Using a unified framework was also aimed at promoting private sector investments in infrastructure, which steadily declined since 2011. To help counter this, the government raised the amount of PPP investment targets by widening the scope of PPP applications and governmentprocured infrastructure projects that can be converted into PPPs. To do this, it was essential to devise an implementation process that introduced PPPs as an alternative procurement method for traditionally procured government infrastructure projects. For this, a unified procedure was needed to review government-procured and PPP projects. Under the framework, the Ministry of Economy and Finance selects a project for which preliminary feasibility study and value-for-money test are conducted. Based on the Republic of Korea's experiences, the unified framework ensures that the modality that offers the best value for money is chosen. Indonesia and the Philippines would benefit from using a unified framework to be able to assess their PPP and government-procured investment projects more objectively. Doing this will also benefit the management of their public finances.

All three countries discussed in this paper have legal bases for PPPs that allow for unsolicited proposals. The Philippines and Indonesia give precise conditions for unsolicited proposals to prevent them from being overused, and for procurement procedures to enhance transparency and invite thirdparty participation. The Republic of Korea, in 2016, relaxed its regulations on unsolicited proposals by allowing private proposals for BTL projects. Unlike developed countries, which prepare projects that attract private investors without relying on unsolicited proposals, the Republic of Korea promotes unsolicited proposals to expand the participation of small and medium-sized companies and financial investors in PPPs. Even though PIMAC scrutinizes unsolicited proposals using mandatory value-formoney tests, the government still evaluates these proposals to ensure their alignment with its investment needs and competitive procurement processes. To keep the market competitive, the procedure must allow sufficient time for bidders other than the project proponent to make their proposals.

\section{Well-Functioning Institutions}

A second tier of well-functioning institutions and processes are needed to implement laws, regulations, rules, and policies on PPPs. Without proper institutional arrangements, projects will be harder to develop and implementing agencies will not be able to function effectively.

The PPP institutional systems in the Philippines and the Republic of Korea center on their ministries of finance, while Indonesia's system is dispersed among several agencies. For example, the Indonesian Ministry of Finance secures budgets for PPP projects and plans and provides government financial support for PPPs, while the National Development Planning Agency (BAPPENAS) oversees project evaluations and management and builds the capacity of other agencies to handle PPPs. The Indonesia Investment Coordinating Board, meanwhile, provides information on the PPP system and projects to investors, and the Coordinating Ministry for Economic Affairs of Indonesia coordinates PPPs with relevant organizations. To ensure a stable and systematic institutional system for PPPs, the 
government should clearly set out the functions of all ministries and government institutions for working on PPPs to avoid overlaps and conflicts of interest.

All three countries have national support agencies for PPPs for project development, feasibility studies, and project evaluations, though there are differences in their functions and roles. The Republic of Korea's PIMAC is an independent body, the Philippines' PPP Center is attached to NEDA, and Indonesia has two central government PPP units. PIMAC may not finance PPP projects, but the PPP units of Indonesia and the Philippines can.

\section{Risk Sharing}

Private investors will only come in on government infrastructure projects if they are confident of earning a decent rate of return on their investment. Especially for the early stages of PPP transactions, private partners require government financial support or guarantees to cover certain risks. Governments, for their part, want their infrastructure projects to be bankable, and they use a range of supportive instruments to achieve this.

All three countries have policy measures to promote infrastructure PPPs. The Philippines makes viability gap funding available for solicited PPP projects that are economically viable but not financially attractive. Viability gap funding is also available for infrastructure PPPs in Indonesia. The Republic of Korea provides financial support to resolve financial feasibility problems that may occur in an infrastructure PPP. A construction subsidy, for example, can be given to a special purpose vehicle if the competent authority deems it necessary for maintaining user fees at a certain level.

Inadequate right-of-way acquisition processes and government budgets for land acquisition are hindering the implementation of infrastructure PPPs in Indonesia and the Philippines. Compulsory land acquisitions are controversial and take time to resolve, and the governments of both countries are taking steps to tackle this problem. In the Republic of Korea, the competent authority may, if necessary, buy land for an infrastructure PPP and let the concessionaire use it free of charge until project completion. In Indonesia, land acquisition is an obligation of the government contracting agency, and Presidential Regulation No. 30 of 2015, allows investors to prefinance land acquisition, which is later recovered by the government. In the Philippines, the Public-Private Partnership Strategic Support Fund reduces the risk of project delays or cancellations because of land acquisitions by helping the government meet the cost of land acquisitions or doing preparatory work on land acquisitions. Despite these efforts, all three countries need to do more to ensure a smoother path for land acquisitions by providing efficient processes with list of land compensation, timelines, financing schedules, and plans and formulas for compensating landowners.

\section{POLICY RECOMMENDATIONS AND CONCLUSION}

Based on the comparative analysis of the PPP systems in Indonesia, the Republic of Korea, and the Philippines, it is imperative to clearly and effectively communicate national infrastructure plans with the public and end users, as widespread opposition to infrastructure PPPs in all three countries is apparent for reasons discussed earlier. The governments of these countries need to establish stakeholder engagement strategies and consultations on planned projects should be held with civil groups to be able to understand early on possible objections to the project. 
On improving legal and regulatory frameworks, Indonesia and the Philippines need to set up frameworks to reduce or resolve disputes more flexibly, and this will require building the knowledge of officials working on PPPs in this area. Both countries also need to adopt a unified framework for integrating PPPs and government-procured investment projects, rather than managing them separately-a practice that undermines the efficient management of public finance and creates fiscal risk.

All three countries have legal bases for PPPs that allow for unsolicited proposals. The Republic of Korea needs to establish policy measures for preventing unsolicited proposals from being overused, and to ensure their alignment with the country's investment needs.

While the PPP institutional systems in the Philippines and the Republic of Korea are more centralized in their ministries of finance, Indonesia's system is dispersed among several agencies with roles and functions somewhat duplicated and not clear. To ensure a stable and systematic institutional system for PPPs, Indonesia should clearly set out the functions of all ministries and government institutions for working on PPPs to avoid overlaps and conflicts of interest.

In all three countries, inadequate right-of-way acquisition processes and government budgets for land acquisition are hindering the implementation of infrastructure PPPs. Governments are trying to tackle this problem, but current efforts are inadequate. Although not exhaustive, the comparative analysis of the three countries showed that enabling legal, institutional, and policy environments are critical for the successful implementation of infrastructure PPPs. Policy reform efforts (to varying degrees) are being undertaken by governments to address existing challenges but, going by the measures taken so far, bolder steps need to be taken. 


\section{REFERENCES}

Asian Development Bank (ADB). 2017a. Meeting Asia's Infrastructure Needs. Manila

2017b. Asian Development Outlook 2017 Update: Sustaining Development through Public-Private Partnership. Manila.

Asian Development Bank (ADB) and Korea Development Institute (KDI). 2011. Public-Private Partnership Infrastructure Projects: Case Studies from the Republic of Korea. Manila: ADB, Seoul: KDI.

Economist Intelligence Unit (EIU). 2015. "Evaluating the Environment for Public-Private Partnerships in AsiaPacific: The 2014 Infrascope." http://www.adb.org/publications/evaluatingenvironmentppp-asiapacific-2014-infrascope.

Inter-American Development Bank (IDB). 2014. Sustainable Infrastructure for Competitiveness and Inclusive Growth. Washington, DC.

Kim, Jay-Hyung, Jungwook Kim, Sunghwan Shin, and Sueng-yeon Lee. 2011. Public-Private Partnership Infrastructure Projects: Case Studies from the Republic of Korea: Volume 1: Institutional Arrangements and Performance. Manila: Asian Development Bank.

Korea Development Institute (KDI). 2015. A Comparison Study on the PPP System of Korea, Philippines and Indonesia. Sejong.

Ministry of Strategy and Finance, Government of the Republic of Korea. 2015. Public-Private Partnership Projects Promotion Plan. Sejong.

2017. Public-Private Partnership Basic Plans. Sejong.

National Development Planning Agency. 2015. Public Private Partnerships. Infrastructure Projects Plan in Indonesia 2015. Jakarta.

Public-Private Partnership Center of the Philippines (PPP Center). 2012. Project Development and Monitoring Facility Guidelines. Manila.

2014. National Government Agency Public-Private Partnership Manual. Manila.

Ricote, Eleazar. 2016. "The Philippine PPP Program: Experience and Lessons.” Paper presented at the Symposium on Regional Best Practices in PPPs. Australia Awards Office Indonesia. Jakarta, September 5. 


\section{Public-Private Partnership Systems in the Republic of Korea, the Philippines, and Indonesia}

This paper analyzes the public-private partnership (PPP) systems in the Republic of Korea, the Philippines, and Indonesia. It underscores how strong institutions, unified procurement frameworks, and effective dispute resolution mechanisms can improve the implementation of infrastructure PPPs in these countries. A comparative analysis also draws lessons for other economies in Asia and the Pacific that are seeking to improve the efficiency and effectiveness of their PPPs.

\section{About the Asian Development Bank}

ADB is committed to achieving a prosperous, inclusive, resilient, and sustainable Asia and the Pacific, while sustaining its efforts to eradicate extreme poverty. Established in 1966, it is owned by 67 members48 from the region. Its main instruments for helping its developing member countries are policy dialogue, loans, equity investments, guarantees, grants, and technical assistance. 